\title{
Kemampuan Berpikir Kritis dan Motivasi Belajar Siswa Melalui Pemberian Tugas Terstruktur dan Tugas Mandiri Pada Materi Sistem Gerak Pada Manusia di Kelas VIII MTs Negeri 2 Makassar
}

\author{
Ability of Critical Thinking and Student Learning Motivation \\ Through The Delivery of Designed and Mutual Duties On The \\ Motorized System Material On Human In Class VIII MTs Negeri 2 \\ Makassar
}

\author{
Supiana $^{1)^{*}}$, Muthahhir Muchtar ${ }^{2)}$ \\ ${ }^{1)}$ MTsN 2 Makassar \\ ${ }^{2)}$ MTsN 1 Makassar
}

Received $4^{\text {th }}$ April 2018/Accepted $27^{\text {th }}$ June 2018

\begin{abstract}
ABSTRAK
Penelitian ini bertujuan untuk mengetahui perbedaan kemampuan berfikir kritis dan motivasi belajar melalui pemberian tugas terstruktur dan tugas mandiri pada siswa kelas VIII-9 dan VIII-10 MTsN 2 Makassar Pada Materi Sistem Gerak Pada Manusia. Desain penelitian ini adalah penelitian eksperimen (quasi experiment). Populasi dan sampel adalah siswa kelas VIII-9 dan VIII-10 MTsN 2 Makassar Tahun Pelajaran 2017-2018. Data yang dikumpulkan berupa tes kemampuan berfikir kritis dan tes motivasi belajar. Data yang diperoleh dianalisis secara deskriptif dan inferensial dengan memaparkan mean, standar deviasi, dan presentase sedangkan analisis inferensial digunakan untuk menguji hipotesis melalui uji t-test dan sebelum dilakukan uji t-test terlebih dahulu uji normalitas dan homogenitas varians. Hasil penelitian menunjukkan ada perbedaan kemampuan berpikir kritis yang signifikan antara kelas eksperimen tugas terstruktur dan kelas eksperimen tugas mandiri, yang dibuktikan dengan nilai thitung data yaitu (5,31). Dimana berdasarkan kriteria uji maka dapat dikatakan bahwa $\mathrm{H}_{0}$ ditolak karena nilai thitung lebih besar dibanding nilai tabel $(1,67)$. Ada perbedaan motivasi belajar antara kelas eksperimen tugas terstruktur dan kelas eksperimen tugas mandiri, yang dibuktikan dengan nilai motivasi belajar tugas terstruktur $(3,37)$ lebih rendah dibanding motivasi belajar tugas mandiri (3,54), dan nilai thitung (1,70). Dimana berdasarkan kriteria uji maka dapat dikatakan bahwa $H_{0}$ ditolak karena nilai thitung lebih besar dibanding nilai $t_{\text {tabel }}(1,67)$.
\end{abstract}

Kata kunci: Berfikir kritis, motivasi belajar.

*Korespondensi:

email: supianamh@gmail.com 
Kemampuan Berpikir Kritis dan Motivasi Belajar Siswa Melalui Pemberian Tugas Terstruktur dan Tugas Mandiri Pada Materi Sistem Gerak Pada Manusia di Kelas VIII MTs Negeri 2 Makassar

\begin{abstract}
This study aims to determine the differences of critical thinking skills and motivation to learn through the assignment of structured and independent tasks on students of class VIII-9 and VIII-10 MTsN 2 Makassar On Motion System Material In Humans. The design of this research is experimental research (quasi experiment). Population and sample are students of class VIII-9 and VIII-10 MTsN 2 Makassar Lesson 2017-2018. Data collected in the form of critical thinking skills tests and motivation test learning. The data obtained were analyzed descriptively and inferentially by describing the mean, standard deviation, and percentage whereas the inferential analysis was used to test the hypothesis through $t$-test and before the first t-test was tested normality test and homogeneity of variance. The result of the research shows that there is significant difference of critical thinking ability between experimental class of structured task and experimental class of independent duty, as evidenced by the data tcount $(5,31)$. Where based on the test criteria it can be said that $H_{0}$ is rejected because the value of $t$ count is greater than the value of $t_{\text {table }}$ (1.67). There is a difference in learning motivation between the experimental class of structured tasks and the experimental class of independent tasks, as evidenced by the value of learning motivation of structured task (3.37) lower than the self-learning task motivation (3.54), and $t_{\text {count }}(1.70)$. Where based on the test criteria it can be said that $H_{0}$ is rejected because the value of $t$ count is greater than the value of $t_{\text {table }}$ (1.67).
\end{abstract}

Keywords: Critical thinking, learning motivation.

\title{
PENDAHULUAN
}

Salah satu tolak ukur keberhasilan guru adalah bila dalam proses mengajar mencapai hasil yang optimal. Keberhasilan ini sangat dipengaruhi oleh kemampuan guru untuk mengelola proses belajar mengajar. Proses pembelajaran pada satuan pendidikan diselenggarakan secara interaktif, inspiratif, menyenangkan, menantang, memotivasi peserta didik untuk berpartisipasi aktif, serta memberikan ruang yang cukup bagi prakarsa, kreativitas, dan kemandirian sesuai dengan bakat, minat, dan perkembangan fisik serta psikologis peserta didik.

Di MTsN 2 Makassar khususnya kelas VIII belum terlihat jelas pengimplementasian kemampuan berpikir kritis . Hal ini berdasarkan observasi awal, bahwa guru umumnya menggunakan model pembelajaran yang bervariasi (berganti-ganti) untuk meningkatkan pemahaman konsep biologi pada siswa, belum tampak kesadaran guru untuk memberdayakan kemampuan berpikir kritis siswa melalui tugas terstruktur dan tugas mandiri.

Menurut Sri Sulistyorini (1998: 85), kemampuan berpikir kritis mengacu pada "kebenaran" (truth) yang bertumpu pada kriteria, aturan-aturan dan hukum. Sementara itu kemampuan berpikir kreatif mengacu pada "kebermaknaan" (meaning) yang merujuk pada nilai guna dan kemanfaatannya. Meskipun kedua jenis kemampuan itu berbeda namun keberadaannya tidak bisa dipisahkan. Artinya tidak ada kreativitas tanpa disertai daya kritis, demikian pula sebaliknya daya kritis selalu disertai proses kreatif. 
Pola pembelajaran yang dikembangkan di Indonesia dewasa ini, menuntut keaktifan siswa dalam proses kegiatan belajar mengajar dan juga menuntut kreativitas siswa untuk mengolah data yang diberikan guru. Menurut Spliter (1991, dalam Redhana 2003: 1213), agar terjadi pengkontruksian pengetahuan secara bermakna, guru haruslah melatih siswa agar berpikir secara kritis dalam menganalisis maupun dalam memecahkan suatu permasalahan. Siswa yang berpikir kritis adalah siswa yang mampu mengidentifikasi, mengevaluasi, dan mengkontruksi argumen serta mampu memecahkan masalah dengan tepat. Siswa yang berpikir kritis akan mampu menolong dirinya atau orang lain dalam memecahkan permasalahan yang dihadapi siswa. Pemberian tugas terstruktur dan tugas mandiri merupakan salah satu stategi belajar mengajar untuk mengoptimalkan kegiatan belajar siswa. Tugas terstruktur diberikan kepada siswa dan ditindaklanjuti akan meningkatkan hasil belajar siswa. Pemberian tugas terstruktur diberikan untuk melatih siswa dalam menyelesaikan soal-soal atau permasalahan-permasalahan yang berkaitan dengan pengajaran yang baru diajarkan. Tugas mandiri dapat pula mengoptimalkan siswa yang merupakan tugas rumah sehingga siswa memiliki banyak waktu dan sumber yang tak terbatas dalam memecahkan masalah yang ada. Dimana tugas terstruktur dan tugas mandiri diberikan agar supaya siswa dapat menguasai materi pelajaran dan dapat memberikan motivasi bagi siswa dalam meningkatkan prestasi belajarnya.

Berangkat dari latar belakang tersebut, penulis melakukan penelitian dengan judul "Kemampuan Berpikir Kritis dan Motivasi Belajar Siswa Melalui Pemberian Tugas Terstruktur dan Tugas Mandiri pada Materi Sistem Gerak pada Manusia di Kelas VIII MTsN 2 Makassar”

\section{METODE PENELITIAN}

Jenis penelitian ini adalah penelitian eksperimen semu (quasi experiment). Eksperimen yang dimaksud adalah untuk mengetahui ada tidaknya perbedaan kemampuan berpikir kritis siswa akibat pemberian model/ strategi pembelajaran yang berbeda.

Desain penelitian ini adalah desain penelitian post test nonequivalent grup design yang nampak sebagai berikut.

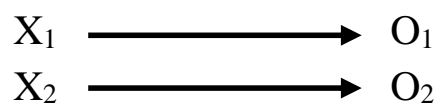

(Wiersma, $1995: 141$ )

Keterangan :

$\mathrm{X}_{1}=$ pemberian tugas terstruktur

$\mathrm{X}_{2}=$ pemberian tugas mandiri

$\mathrm{O}_{1}=$ kemampuan berpikir kritis dan motivasi belajar yang diajar melalui pemberian tugas terstruktur

$\mathrm{O}_{2}=$ kemampuan berpikir kritis dan motivasi belajar yang diajar melalui tugas mandiri

Instrumen yang digunakan dalam penelitian ini adalah test kemampuan berpikir kritis dan lembar inventory motivasi belajar siswa. Tes kemampuan berpikir kritis siswa dari kelas eksperimen pemberian tugas terstruktur dan tugas mandiri akan direkam dalam 
tabulasi skor kemampuan berpikir kritis siswa. Soal-soal pada tes kemampuan berpikir kritis berupa materi yang berkaitan dengan pokok bahasan Sisten gerak pada manusia. Soal-soal tersebut berupa soal essay yang berjumlah 5 butir soal yang mengacu pada karakteristik atau indikator kemampuan berpikir kritis. Sistem penilaian didasarkan pada kesesuaian dan ketepatan jawaban yang diberikan oleh siswa. Sedangkan instrumen motivasi belajar menggunakan Inventori yang di adapatasi dari belajarpsikologi.com.

Data dalam penelitian ini akan dianalisis dengan menggunakan aplikasi software SPSS 17.0 untuk mengetahui statistik deskriptif dan inferensial. Analisis deskriptif digunakan untuk menggambarkan data penelitian dalam bentuk mean (rata-rata), standar deviasi, dan presentase. Sedangkan analisis inferensial digunakan untuk menguji hipotesis melalui uji t-test, tetapi sebelum dilakukan uji t-test diperiksa terlebih dahulu uji normalitas data hasil penelitian dan homogenitas varians kelompok data. Untuk mendeskripsikan data motivasi belajar, digunakan kriteria interpretasi penelitan. Motivasi dianggap meningkat/ baik bila secara klasikal mendapat nilai $\geq 3,5$ pada skala $1-4$.

\section{HASIL DAN PEMBAHASAN}

\section{Hasil Analisis Statistik Deskriptif}

Distribusi Nilai Tugas Terstruktur dan Tugas Mandiri Siswa

Nilai tugas terstruktur siswa pada kelas VIII-9 dengan materi sistem rangka mempunyai nilai berkisar antara 40 sampai 80 dengan rata-rata nilai $=65,78$. Sedangkan nilai tugas mandiri siswa pada kelas VIII-10 dengan materi sistem rangka mempunyai nilai berkisar 60 sampai 90 dengan rata-rata nilai $=71,40$. Deskripsi nilai tugas terstruktur dan tugas mandiri dapat dilihat pada Tabel 1.

Tabel 1. Deskripsi Nilai Tugas Terstruktur (TT) Siswa Kelas VIII-9 dan Nilai Tugas Mandiri (TM) Siswa Kelas VIII-10

\begin{tabular}{|c|c|c|c|}
\hline \multicolumn{4}{|c|}{ Statistics } \\
\hline & & TT & TM \\
\hline \multirow{2}{*}{$\mathrm{N}$} & Valid & 32 & 32 \\
\hline & Missing & 0 & 0 \\
\hline \multicolumn{2}{|c|}{ Mean } & 65.7813 & 71.4063 \\
\hline \multicolumn{2}{|c|}{ Median } & 65.0000 & 70.0000 \\
\hline \multicolumn{2}{|c|}{ Mode } & 65.00 & 70.00 \\
\hline \multicolumn{2}{|c|}{ Std. Deviation (SD) } & 11.36700 & 9.43863 \\
\hline \multicolumn{2}{|c|}{ Variance } & 129.209 & 89.088 \\
\hline \multicolumn{2}{|c|}{ Range } & 40.00 & 30.00 \\
\hline \multicolumn{2}{|c|}{ Minimum } & 40.00 & 60.00 \\
\hline \multicolumn{2}{|c|}{ Maximum } & 80.00 & 90.00 \\
\hline \multicolumn{2}{|c|}{ Sum } & 2105.00 & 2285.00 \\
\hline
\end{tabular}


Dari data tersebut diketahui bahwa nilai tengah (median) dan yang sering muncul (modus) TT yaitu 65 dan TM yaitu 70. Selanjutnya nilai sumulatif TT memperoleh nilai sebesar 2105, dan TM sebesar 2285. Selain itu, deviasi standar (penyimpangan/ bias) dan varians yang diperoleh dari data di atas secara berurutan yaitu TT sebesar 11,36 dan 129.20, dan TM sebesar 9,43 dan 89,08. Hal ini menandakan bahwa kumpulan data di atas tidak terlalu bias karena nilai yang diperoleh mendekati nol (titik normal data).

Nilai Kemampuan Berpikir Kritis Tugas Terstruktur (KBK TT) siswa pada kelas VIII-9 dengan materi sistem rangka mempunyai nilai berkisar antara 40 sampai 80 dengan rata-rata nilai $=62,5$. Sedangkan nilai Kemampuan Berpikir Kritis Tugas Mandiri (KBK TM) siswa pada kelas VIII-10 dengan materi sistem rangka mempunyai nilai berkisar 60 sampai 90 dengan rata-rata nilai $=74,65$. Deskripsi nilai KBK TT dan KBK TM dapat dilihat pada Tabel 2 .

Tabel 2. Distribusi Nilai Tes Kemampuan Berpikir Kritis Siswa Melalui Pemberian Tugas Terstruktur dan Mandiri

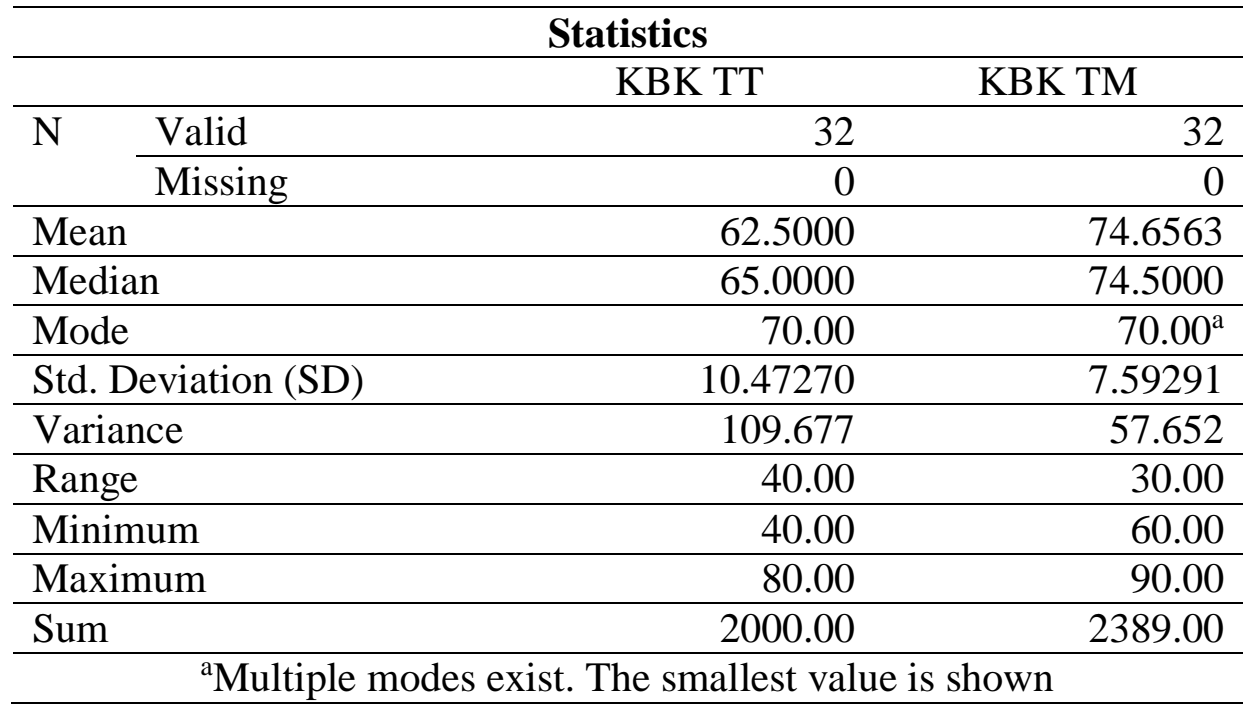

Dari data tersebut diketahui bahwa nilai tengah (median) dan yang sering muncul (modus) KBK TT yaitu 65 dan TM yaitu 74,5. Selanjutnya nilai sumulatif KBK TT memperoleh nilai sebesar 2000, dan KBK TM sebesar 2389. Selain itu, deviasi standar (penyimpangan/ bias) dan varians yang diperoleh dari data di atas secara berurutan yaitu KBK TT sebesar 10,47 dan 109.67, dan KBK TM sebesar 7.59 dan 57,65. Hal ini menandakan bahwa kumpulan data di atas tidak terlalu bias karena nilai yang diperoleh mendekati nol (daerah/ titik normal data). 
Kemampuan Berpikir Kritis dan Motivasi Belajar Siswa Melalui Pemberian Tugas

Terstruktur dan Tugas Mandiri Pada Materi Sistem Gerak Pada Manusia di Kelas VIII MTs Negeri 2 Makassar

Distribusi Nilai Motivasi Belajar Siswa Melalui Pemberian Tugas Terstruktur dan Tugas Mandiri

Nilai Motivasi Belajar Tugas Terstruktur (MB TT) siswa pada kelas VIII-9 dengan materi sistem rangka mempunyai nilai berkisar antara 1,6 sampai 4,1 dengan rata-rata nilai $=3,37$. Sedangkan nilai Motivasi Belajar Tugas Mandiri (MB TM) siswa pada kelas VIII-10 dengan materi sistem rangka mempunyai nilai berkisar 3 sampai 4,1 dengan ratarata nilai $=3,54$. Deskripsi nilai MB TT dan MB TM dapat dilihat pada Tabel 3 .

Tabel 3. Deskripsi Nilai MB TT Siswa Kelas VIII-9 dan Nilai MB TM Siswa Kelas VIII-10

\begin{tabular}{lrrr}
\hline \multicolumn{4}{c}{ Statistics } \\
\hline \multicolumn{3}{c}{ MB TT } & MB TM \\
\hline $\mathrm{N}$ & Valid & 32 & 32 \\
\cline { 2 - 4 } \multicolumn{1}{c}{ Missing } & 0 & 0 \\
\hline Mean & 3.3719 & 3.5406 \\
\hline Median & 3.5000 & 3.5000 \\
\hline Mode & 3.50 & 3.50 \\
\hline Std. Deviation (SD) & .46989 & .30676 \\
\hline Variance & .221 & .094 \\
\hline Range & 2.50 & 1.10 \\
\hline Minimum & 1.60 & 3.00 \\
\hline Maximum & 4.10 & 4.10 \\
\hline Sum & 107.90 & 113.30 \\
\hline
\end{tabular}

Dari data di atas diketahui bahwa nilai tengah (median) dan yang sering muncul (modus) MB TT yaitu 3.37 dan TM yaitu 3,54. Selanjutnya nilai sumulatif MB TT memperoleh nilai sebesar 107.9, dan MB TM sebesar 113,3. Selain itu, deviasi standar (penyimpangan/ bias) dan varians yang diperoleh dari data di atas secara berurutan yaitu MB TT sebesar 0,46 dan 0.22, dan MB TM sebesar 0,30 dan 0,09. Hal ini menandakan bahwa kumpulan data di atas tidak bias karena nilai yang diperoleh mendekati nol (daerah/ titik normal data).

\section{Hasil Analisis Inferensial}

Uji Normalitas Data

Uji normalitas yang digunakan dalam analisis data penelitian ini yaitu melalui analisa grafik P-Plot. Dimana pada grafik akan nampak titik-titik bulat yang merupakan simbol dari nilai-nilai dari tiap distribusi. Selanjutnya, titik-titik bulat tersebut akan berada di sekitar garis normal. Jika titik-titik tersebut mendekati garis normal, maka diasumsikan bahwa data berdistribusi normal. Begitu pula sebaliknya. Berdasarkan grafik lampiran 9, dapat disimpulkan bahwa nilai-nilai dari tiap distribusi di atas berdistribusi normal karena semua titik mendekati garis normal, dan uji homogenitas dapat dilanjutkan. 


\section{Uji Signifikansi Koefisien Korelasi}

Korelasi korelasi dimaksudkan untuk mencari hubungan antarvariabel, yaitu variabel bebas (independent) dan variabel terikat (dependent). Dimana besarnya koefisien menggambarkan seberapa erat hubungan linear antara dua peubah. Peubah yang terlibat kedua-duanya bertipe numerik dan menyebar normal jika ingin pengujian terhadapnya bersifat sah.

Berdasarkan hasil analisis (lampiran 9), diketahui bahwa korelasi antara TT dengan KBK TT, TT dengan MB TT, dan TM dengan MB TM tidak signifikan. Hal ini dikarenakan nilai signifikansi perolehannya lebih besar dari nilai $\alpha$ sehingga dapat dikatakan bahwa jika nilai variabel bebasnya (TT/ TM) tinggi, maka nilai variabel terikatnya (KBK TT, MB TT, dan MB TM) rendah, dan jika nilai variabel bebasnya (TT/ $\mathrm{TM})$ rendah, maka nilai variabel terikatnya (KBK TT, MB TT, dan MB TM) tinggi Sedangkan korelasi antara TM dengan KBK TM adalah signifikan karena nilai signifikansinya lebih kecil dari nilai $\alpha$ sehingga dapat dikatakan bahwa jika nilai variabel bebasnya (TM) tinggi, maka nilai variabel terikatnya (KBK TM) juga tinggi, dan jika nilai variabel bebasnya (TM) rendah, maka nilai variabel terikatnya (KBK TM) juga rendah. Untuk lebih jelasnya, nilai signifikansi dari setiap variabel dapat dilihat pada Tabel 4.

Tabel 4. Nilai Signifikansi Korelasi Tiap Variabel Penelitian

\begin{tabular}{cccl}
\hline Variabel & Nilai Signifikansi & Nilai $\boldsymbol{\alpha}$ & Keterangan \\
\hline TT dan KBK TT & 0,18 & 0,05 & Tidak Signifikan \\
TT dan MB TT & 0,07 & 0,05 & Tidak Signifikan \\
TM dan KBK TM & 0,03 & 0,05 & Signifikan \\
TM dan MB TM & 0,59 & 0,05 & Tidak Signifikan \\
\hline
\end{tabular}

\section{Uji Homogenitas dan Hipotesis Varians Data}

Uji homogenitas dan hipotesis varians data penelitian ini menggunakan uji independent sample test karena kedua jenis sampel tidak berikatan (berhubungan) atau saling bebas. Artinya kejadian yang ada pada sampel satu belum tentu terjadi pada sampel dua. Kriteria uji homogenitas dari independent sample test yaitu menerima $\mathrm{H}_{0}$ jika nilai signifikansi lebih besar dari nilai $\alpha(0,05)$, dan menolak $\mathrm{H}_{0}$ jika nilai signifikansi lebih kecil dari nilai $\alpha(0,05)$. Pada lampiran 9 (uji homogenitas kemampuan berpikir kritis), diketahui bahwa $F_{\text {hitung }}$ data yaitu 3,55 dengan signifikansi 0,06. Berdasarkan kriteria uji maka dapat dikatakan bahwa $\mathrm{H}_{0}$ diterima karena nilai signifikansinya $(0,06)$ lebih besar dibanding nilai $\alpha(0,05)$. Artinya kemampuan berpikir kritis siswa di kedua kelas mempunyai varians yang homogen $\left(\mathrm{S}_{1}{ }^{2}=\mathrm{S}_{2}{ }^{2}\right)$, dan uji hipotesis dapat dilanjutkan. Sedangkan uji homogenitas motivasi belajar, diketahui bahwa $F_{\text {hitung }}$ data yaitu 2,09 dengan signifikansi 0,15 . Berdasarkan kriteria uji maka dapat dikatakan bahwa $\mathrm{H}_{0}$ diterima karena nilai signifikansinya $(0,06)$ lebih besar dibanding nilai $\alpha(0,05)$. Artinya 
motivasi belajar siswa di kedua kelas mempunyai varians yang homogen $\left(\mathrm{S}_{1}{ }^{2}=\mathrm{S}_{2}{ }^{2}\right)$, dan uji hipotesis dapat dilanjutkan

Selanjutnya kriteria uji hipotesis dari independent sample test yaitu menerima $\mathrm{H}_{0}$ jika nilai $t_{\text {hitung }}$ data lebih besar dari nilai $t_{\text {tabel}}$, dan menolak $\mathrm{H}_{0}$ jika nilai $t_{\text {hitung }}$ data lebih kecil dari nilai $t_{\text {tabel. }}$ Pada lampiran 9 (uji kemampuan berpikir kritis), diketahui bahwa $t_{\text {hitung }}$ data yaitu 5,31 dengan signifikansi 0,00. Berdasarkan kriteria uji maka dapat dikatakan bahwa $\mathrm{H}_{0}$ ditolak karena nilai $t_{\text {hitung }}$ lebih besar dibanding nilai $\mathrm{t}_{\text {tabel }}(1,67)$. Artinya ada perbedaan kemampuan berpikir kritis siswa yang diajar melalui pemberian tugas terstruktur (KBK TT) dengan kemampuan berpikir kritis siswa yang diajar melalui pemberian tugas mandiri (KBK TM). Selanjutnya untuk uji hipotesis motivasi belajar, diketahui bahwa thitung data yaitu 1,70 dengan signifikansi 0,09. Berdasarkan kriteria uji maka dapat dikatakan bahwa $\mathrm{H}_{0}$ ditolak karena nilai thitung lebih besar dibanding nilai tabel $(1,67)$. Artinya ada perbedaan motivasi belajar siswa yang diajar melalui pemberian tugas terstruktur (MB TT) dengan kemampuan berpikir kritis siswa yang diajar melalui pemberian tugas mandiri (MB TM). Untuk lebih jelasnya, dapat dilihat pada tabel 5 berikut.

Tabel 5. Uji Homogenitas dan Hipotesis Data

\begin{tabular}{|c|c|c|c|c|}
\hline Nilai & \multicolumn{2}{|c|}{ Hasil Uji F } & \multicolumn{2}{|c|}{ Hasil Uji t } \\
\hline \multirow{2}{*}{$\mathrm{KBK}$} & $F_{\text {hitung }}$ & Signifikansi & $t_{\text {hitung }}$ & Signifikansi \\
\hline & 3,55 & 0,06 & 5,31 & 0,00 \\
\hline Keterangan & \multicolumn{2}{|c|}{ Varians homogen } & \multicolumn{2}{|c|}{$\begin{array}{c}\text { Ada perbedaan antara KBK TT } \\
\text { dan KBK TM }\end{array}$} \\
\hline \multirow{2}{*}{ MB } & $F_{\text {hitung }}$ & Signifikansi & $t_{\text {hitung }}$ & Signifikansi \\
\hline & 2,09 & 0,15 & 1,70 & 0,09 \\
\hline Keterangan & Varia & mogen & $\begin{array}{r}\text { Ada perbe } \\
\mathrm{d}\end{array}$ & $\begin{array}{l}\operatorname{tara} \mathrm{KBK} \text { TT } \\
\mathrm{TM}\end{array}$ \\
\hline
\end{tabular}

\section{Pembahasan}

Kemampuan berpikir kritis dalam penelitian ini diartikan sebagai serangkaian kemampuan mengemukakan pendapat, menganalisis gambar dan informasi, membedakan, memberi penjelasan dan mengelompokkan yang disusun dalam bentuk tes kemampuan berpikir kritis siswa.

Pada awal proses belajar mengajar yang berlangsung di kedua kelas eksperimen menunjukan tidak ada perbedaan yang menonjol. Siswa sebagian besar belum siap untuk mengikuti pelajaran. Ini dapat dilihat dari pengetahuan awal tentang materi yang akan diajarkan. Siswa hanya mengharapkan informasi dari guru, peran aktif siswa sangat kurang sehingga siswa tidak termotivasi dengan belajar. Pada kedua kelas ekperimen tersebut, nampak tidak terbiasa dengan permasalahan yang diberikan peneliti baik pada tugas terstruktur maupun tugas mandiri yang dikerjakan secara individu. Sehingga 
apabila soal dari lembar kerja siswa dianggap sulit, siswa hanya menyalin jawaban dari siswa lain. Hal ini dapat dilihat dari hasil penilaian tugas siswa.

Menurut Lionor dalam Khalili (2003: 74), berpikir kritis merupakan aktivitas kognitif dan upaya sistematis mental untuk memahami dan memeriksa temuan dan fenomena dan hubungan mereka berdasarkan keterampilan penalaran dan analisis. Oleh karena itu, sehingga apabila siswa tidak terbiasa dengan permasalahan yang menuntut penalaran dan analisis maka siswa akan sulit untuk melakukan berpikir kritis.

Lebih lanjut Daniel T. Wilingham (2007: 10) dalam jurnalnya, menjelaskan bahwa biasanya para siswa fokus pada permasalahan hanya pada struktur permukaannya bukan pada struktur yang mendalam untuk menyelesaikannya. Jadi meskipun siswa telah diajarkan bagaimana untuk memecahkan suatu jenis masalah, ketika permasalahan tersebut terjadi perubahan dari guru atau dari sebuah buku, siswa masih harus berjuang untuk menerapkan solusi karena mereka tidak memahami bahwa pada dasarnya masalah tersebut secara matematis sama.

Berdasarkan hasil analisis deskriptif dari data yang diperoleh melalui hasil tes kemampuan berpikir kritis siswa yang diujikan, pada kelas eksperimen dengan pemberian tugas terstruktur diperoleh rata-rata kemampuan berpikir kritis sebesar 62,50 sedangkan pada kelas eksperimen dengan pemberian tugas mandiri sebesar 74,66. Hal ini menunjukan nilai rata-rata hasil tes kemampuan berpikir kritis dari kedua kelas eksperimen tersebut memiliki perbedaan.

Hasil pengujian hipotesis yang dilakukan menunjukan bahwa ada perbedaan yang signifikan antara kedua kelas eksperimen tersebut yang berarti bahwa ada perbedaan kemampuan berpikir kritis siswa melalui pemberian tugas terstruktur dan tugas mandiri. Hasil ini sama halnya dengan dilakukan Eslami (2003) dengan membandingkan tiga grup perawat dalam kemampuan untuk berpikir kritis. Eslami menyimpulkan bahwa total skor dari ketiga grup tersebut mempunyai perbedaan yang signifikan dan bahkan salah satu grup memiliki penurunan yang signifikan. Hasil dari penelitian ini serupa dengan penelitian di atas, dimana siswa pada kelas eksperimen tugas terstruktur mencapai kemampuan berpikir kritis lebih rendah dibanding siswa di kelas eksperimen tugas mandiri.

Berdasarkan hasil analisis data kemampuan berpikir kritis siswa pada setiap butir soal tersebut menunjukkan bahwa secara klasikal kelas eksperimen dengan penggunaan tugas mandiri memiliki nilai-nilai yang lebih tinggi dibanding kelas eksperimen dengan penggunaan terstruktur. Hal ini disebabkan pada kelas ekperimen tugas mandiri, siswa diberikan tanggung jawab dan pengalaman pribadi untuk menyelesaikan tugas secara individu serta diberikan waktu yang banyak untuk menyelesaikan tugas tersebut sedangkan untuk kelas ekperimen tugas tertruktur baik secara individu maupun kelompok siswa dibiasakan menyelesaikan soal-soal yang terdapat pada tugas terstruktur yang berisi pertanyaan-pertanyaan yang mendorong siswa untuk melakukan proses menganalisis. Dari hasil penelitian Ian Wright dan C. L. Bar (1987), L. M. Sartorelli (1989) dan R. Swartz dan S. Parks (1992) dalam Hassoubah (2004: 96-110), beberapa cara meningkatkan keterampilan berpikir kritis diantaranya adalah dengan meningkatkan daya analisis. Selain itu, Christensen dan Marthin (1992) dalam Redhana (2003: 21) 
menyatakan bahwa strategi pemecahan masalah dapat mengembangkan keterampilan berpikir kritis.

Pemberian tugas terstruktur dilaksanakan di dalam kelas dengan referensi yang dimiliki oleh siswa itu sendiri sehingga siswa dapat menyelesaikan soal tersebut dan mengembangkan kemampuan dan keterampilan mereka secara individu dengan keterbatasan referensi yang ada. Namun yang perlu diketahui bahwa setiap siswa memiliki kemampuan berpikir yang berbeda-beda dalam menganalisis sesuatu jika sumber informasinya juga diperluas sehingga dalam pelaksanaan tugas, siswa lebih mengeksplorasi kemampuannya dalam menjawab soal. Selain itu, siswa dapat salng bertukar gagasan yang aktif di dalam kelompok kecil sehingga tidak hanya menarik perhatian siswa tetapi juga dapat mempromosikan pemikiran kritis (Gokhale, 2002: http://scholar.lib.vt.Edu/enjournals/JTE). Kerjasama dapat memberi kesempatan kepada siswa untuk terlibat dalam diskusi, bertanggung jawab terhadap pelajaran sehingga dengan begitu mereka menjadi pemikir yang kritis (Totten, Ambang, Digby, \& Russ 1991, dalam Gokhale, 2002). Pemberian tugas mandiri merupakan metode yang dapat meningkatkan peran aktif setiap siswa, meningkatkan kesiapan, pemahaman dan penguasaan terhadap materi pelajaran biologi. Oleh karena itu, jika didukung dengan keterlibatan siswa secara individu dalam pelaksanaan pemberian tugas mandiri, maka akan dapat merangsang daya kreativitas yang tinggi dari siswa sehingga dapat memecahkan masalah dari soal yang diberikan.

Hal inilah yang menyebabkan kelas eksperimen tugas mandiri memiliki rata-rata skor evaluasi dan taraf kemampuan berpikir kritis yang tinggi dari kelas ekperimen tugas terstruktur karena memacu siswa untuk lebih melatih kemampuan berpikir kritisnya. Selain itu, siswa diberikan tanggung jawab dan pengalaman pribadi untuk menyelesaikan tugas secara individu sedangkan untuk kelas ekperimen tugas tertruktur baik secara individu maupun kelompok siswa dibiasakan menyelesaikan soal-soal yang terdapat pada tugas terstruktur yang berisi pertanyaan-pertanyaan yang mendorong siswa untuk melakukan proses menganalisis.

Temuan lain yang dapat dikemukakan pada penelitian ini yaitu tentang motivasi belajar. Motivasi belajar siswa diperoleh dengan memberikan lembar inventory yang telah diadaptasi dari belajarpsikologi.com. Temuan ini dimaksudkan untuk melihat hubungan motivasi belajar siswa dengan kemampuannya berpikir kritis. Setelah dianalisis, diketahui bahwa secara klasikal motivasi belajar kelas eksperimen tugas mandiri dikatakan baik. Sedangkan kelas eksperimen tugas terstruktur dikatakan belum baik. Hal ini dapat dilihat dari nilai rata-rata perolehan konversi inventory kelas eksperimen tugas mandiri yang telah mencapai standar interpretasi penelitian yaitu 3,54 sedangkan kelas eksperimen tugas terstruktur belum mencapainya dengan nilai 3,37. Hal ini menandakan bahwa motivasi belajar kelas eksperimen tugas mandiri lebih baik dibanding kelas eksperimen tugas terstruktur.

Menurut Mohamad Surya yang dikutip oleh Sardiman (2004: 91) dalam Nugroho (2011), motivasi dapat diartikan sebagai suatu upaya untuk menimbulkan atau meningkatkan dorongan untuk mewujudkan perilaku tertentu yang terarah kepada pencapaian suatu tujuan tertentu. Dengan motivasi, pelajar dapat mengembangkan 
aktivitas dan inisiatif, dapat mengarahkan dan memelihara ketekunan dalam melakukan kegiatan belajar. Memberikan motivasi kepada seseorang siswa untuk melakukan sesuatu atau ingin melakukan sesuatu. Pada tahap awalnya akan menyebabkan si subjek belajar merasa ada kebutuhan dan ingin melakukan sesuatu kegiatan belajar. Selain itu perlu diketahui bahwa ada tiga faktor yang menentukan hasil belajar yang baik dimana salah satunya adalah motivasi atau komitmen yang tinggi. Berdasarkan hal tersebut di atas, dapat dikatakan bahwa motivasi belajar sangat mempengaruhi hasil belajar seorang siswa, selain dalam proses belajarnya juga ditunjang dengan strategi belajar yang benar.

Berdasarkan hasil penelitian yang telah diperoleh, dapat disimpulkan bahwa kedua kelas eksperimen memiliki nilai rata-rata yang jauh berbeda dengan berdasarkan pada pengujian hipotesis yang menyatakan bahwa ada perbedaan yang signifikan antara kelas eksperimen melalui pemberian tugas terstruktur dan kelas eksperimen melalui pemberian tugas mandiri. Selain itu, penggunaan tugas terstruktur dan tugas mandiri juga mempengaruhi motivasi belajar siswa.

\section{KESIMPULAN}

Berdasarkan hasil dan pembahasan, dapat ditarik beberapa simpulan sebagai berikut.

1. Ada perbedaan kemampuan berpikir kritis yang signifikan antara kelas eksperimen tugas terstruktur dan kelas eksperimen tugas mandiri, yang dibuktikan dengan nilai $t_{\text {hitung }}$ data yaitu $(5,31)$. Dimana berdasarkan kriteria uji maka dapat dikatakan bahwa $\mathrm{H}_{0}$ ditolak karena nilai $t_{\text {hitung }}$ lebih besar dibanding nilai $\mathrm{t}_{\text {tabel }}(1,67)$.

2. Ada perbedaan motivasi belajar antara kelas eksperimen tugas terstruktur dan kelas eksperimen tugas mandiri, yang dibuktikan dengan nilai motivasi belajar tugas terstruktur $(3,37)$ lebih rendah dibanding motivasi belajar tugas mandiri $(3,54)$, dan nilai thitung $(1,70)$. Dimana berdasarkan kriteria uji maka dapat dikatakan bahwa $\mathrm{H}_{0}$ ditolak karena nilai thitung lebih besar dibanding nilai tabel $(1,67)$.

\section{DAFTAR PUSTAKA}

Anonim, 2010. Kemahiran berpikir secara kritis dan kreatif. http;//www.mahirkbkk.tipod.com. Diakses tanggal 13 Juli 2012.

Ali, M., 2004. Guru dalam Proses Belajar Mengajar. Bandung: Sinar Baru Algesindo.

Daniel T. Wilingham., 2007. Critical Thinking : Why Is It So Hard to Teach?. American Federation Of Teachers

Dimyati dan Mudjiono, 2002. Belajar dan Pembelajaran. Jakarta: Rineka Cipta.

Djamarah, S. B., 1991. Strategi Belajar Mengajar Matematika. Jakarta: Rineka Cipta.

Ennis, H, Robert. 1996. Critical Thinking. USA: Prentice-hall inc.

Ennis, R. H., \& Weir, E. (1985). The Ennis-Weir critical thinking essay test, Midwest: Pacific Grove, CA.

Eslami, AR., 2003. The Comparison Of Critical Thinking Among Nurses At Tehran University Of Medical Sciences. Thesis for MS degree on nursing 
Kemampuan Berpikir Kritis dan Motivasi Belajar Siswa Melalui Pemberian Tugas Terstruktur dan Tugas Mandiri Pada Materi Sistem Gerak Pada Manusia di Kelas VIII MTs Negeri 2 Makassar

Fisher, A. 2009. Berpikir Kritis sebuah Pengantar. Jakarta: Erlangga.

Gokhale. Anuradha A. 2002.Collaborative Learning Enhances Critical Thinking. http:// scholar. lib. vt. Edu/ enjournals/ JTE.

Hassoubah, IZ. 2004. Developing Creatif and Critical Thinking Skill (Cara Berpikir Kreatif dan Kritis). Bandung: Nuansa.

Khalili H, Babamohammadi H, Hajiaghajani S., 2003. The Comparison Of The Effect Of Two Teaching Method Classic And Based On Critical Thinking Strategies On Permanent Nursing Students Learning. Semnan Med sci Univ J ;5:53-62.

Nasution, 1997. Berbagai Pendekatan dalam Proses Belajar Mengajar. Jakarta: Bina Aksara.

Poerwanto, 1990. Psikologi Pendidikan. Bandung: PT Remaja Rosdakarya.

Redhana, I Wayan. 2003. Meningkatkan Keterampilan Berpikir Kritis Siswa melalui Pembelajran Kooperatif dengan Strategi Pemecahan Masalah. Jurnal Pendidikan dan Pengajaran no 3 Tahun XXXVI Juli 2003. Singaraja: IKIP Negeri Singaraja.

Roestiyah, NK., 1986. Makalah Ilmu Keguruan. Bandung: Remaja Rosdakarya.

Riduwan, M.B.A., 2009. Dasar-Dasar Statistika. Bandung: ALFABETA.

Rusyan, A., 1994. Kemampuan Dasar Guru dan Proses Belajar Mengajar. Bandung: Remaja Rosdakarya.

SriSulistyorini. 1998. Pengembangan Paket Pembelajaran dengan Model "Flex Your Brain" (Penalaran) pada Pembelajaran Biologi untuk Meningkatkan Kemampuan Berpikir Kritis dan Metakognisi Siswa di SMU N 18 Surabaya. [Thesis]. Surabaya: IKIP Surabaya.

Sudjana, N., 2008. Penilaian Hasil Proses Belajar Mengajar. Bandung: PT. Remaja Rosdakarya.

Suyono dan Hariyanto. 2011. Belajar dan Pembelajaran. Bandung: Remaja Rosdakarya.

Tapilouw, M., 1991. Pengajaran Matematika di Sekolah dasar dengan Pendekatan CBSA. Bandung: Remaja Rosdakarya.

Wiersma, W. 1995. Research Methods In Education. USA: Chestnut Hill Enterprises.

Wijaya, 1996. Pendidikan Remedial (Sarana Pengembanan Mutu Sumber Daya Manusia). Bandung: PT Remaja Rosdakarya.

Winkel, W. S., 1991. Psikologi Pengajar. Grasindo. http ://gurupembaharu.com/artikel/berpikir-kritis. Diakses pada tanggal 13 Juli 2012 